\begin{tabular}{|c|c|c|}
\hline $\begin{array}{c}\text { PORT SAID ENGINEERING RESEARCH JOURNAL } \\
\text { Faculty of Engineering - Port Said University } \\
\text { Volume } 17 \text { No. } 1 \text { pp: 100:105 }\end{array}$ & \\
\hline
\end{tabular}

\title{
Assessment Of The MBR System For Segregated Household Wastewater By Using Simulation Mathematical Model
}

\author{
Amr M. Abdel_Kader
}

\begin{abstract}
Domestic water recycling for several purposes is regarded as an attractive option for the countries where a water scarcity is prevailing. Two groups of wastewater streams are usually recognized as black and grey water at household level. This study analyses the reliability of an on-site MBR system for segregated household wastewater treatment and reuse. To achieve this goal simulation model was developed based on the IWA Activated Sludge Model 1 (ASM1). The MBR model was adapted to describe biological and physical mechanisms for the MBR system. The GPS-X (version 5.0) simulation program was used in this study to simulate the proposed MBR plant model. The experimental data which used on the model calibration and verification were taken from experimental work done at Tubitak, Marmara Research Center, Turkey. Model results were found to agree well with experimental data from two MBRs pilot plants. The grey and black water originated from lodging houses were used as influent wastewater for the two MBRs pilot plants. The two pilot plants were operated for a period of 50 days with hydraulic retention time (HRT) of 18 and 36h respectively for grey and black water. The average removal efficiencies were, 95\% COD, 92\% TN, and 99\% TSS for grey water and $96 \% \mathrm{COD}, 89 \% \mathrm{TN}$, and $99 \%$ TSS for black water. The results showed that the effluent quality of grey and black water treated by the MBR complied with the international reuse criteria for different uses. The MBR plant model is powerful tool for optimizing the treatment process and improving the plant operations. Also, the model can be saving significant cost by predicting the outcome of operational changes, as well as, by performing an energy cost analysis.
\end{abstract}

Keywords: Grey water, Black water, Membrane Bioreactor; Mathematical Model; Wastewater Treatment, Wastewater Reuse.

\section{INTRODUCTION}

Increasing fresh water demand due to rapid population growth and, contamination of both surface and groundwater, periodic droughts as well as uneven distributions of water resources, have lead scientists to focus deeply on the development of new concepts and technologies to conserve water resources. Furthermore, climate change is beginning to create the necessity for implementing more environmentally sustainable solutions and innovative developments. Various studies have been carried out to develop new concepts and innovative technologies for better preservation of water resources worldwide. The uses of reclaimed and treated wastewater are become one of the challenging and key methods being considered to reduce and conserve potable water use. Hence, domestic water recycling for several purposes is regarded as an attractive option for the countries or regions where a water scarcity is prevailing. Two groups of wastewater streams are usually recognized as black and grey water at household level. Black water consists of a mixture of faeces, urine and transport water and may pose potential health risks [1]. Grey water is generally defined as low level polluted wastewater originating from bathtubs, showers, hand washing basins and washing machines, including or excluding kitchen sink waste [2].

Sanitary Eng. Dept., Faculty of Eng., Alexandria University, Alexandria,Egypt,E mail: amr_abdel_kader@yahoo.com Along these lines, sustainable treatment options applicable for grey and black water can be facilitated by considering the advantages of the reuse potential for various purposes such as flushing toilets, cleaning water and for crop or land irrigation.

Although there have been studies on grey water and recycling in the literature for many years [2-6], black water treatment by MBR for reuse is sill an innovative concept. Grey water has always been considered more attractive than black water for researchers due to the high levels of grey water generation, low pollutant characteristics ease of treatment systems design, and the implementation and operation of alternative methods. Recently, membrane bioreactors (MBR) have been used for grey water treatment because of their compactness and superior water reuse potential due to the complete disinfection achieved by micro- or ultrafiltration membranes [5-7]. The utilization of MBRs may be also a promising alternative for black water treatment. The key importance of MBRs is their ability to produce high quality effluent almost free from bacteriologic organisms. Furthermore, MBRs exhibit good resistance to shock loadings and have extensive automation capabilities $[6,8,9]$.

MBR systems are especially attractive for on site grey water treatment and reuse in densely populated urban areas due to incorporation of a biological treatment stage, efficient separation and small footprint. To date, not that 
many full scale systems were installed and even less were monitored for a long period of time in order to analyze their long term performance. This is the objective of this paper: to analyze the reliability of an onsite MBR system for treatment and reuse of grey water and black water. As a first step to achieve this goal, a simulation model was developed based on the IWA Activated Sludge Model 1 (ASM1, Henze et al. 2000). The equations of the ASM1 model were adapted to describe the biological and physical mechanisms occurring in an MBR based system. Model results were compared with experimental results of an on-site of two pilot plants for grey and black water treatment. Once validated, the model was further developed to be run in different scenarios to providing statistical data on the MBR system performance [11].

The modular program used in this study is GPS-X which is a modular, multi-purpose modeling environmental for the simulation of municipal and industrial wastewater treatment plants. GPS-X uses an advanced graphical user interface to facilitate dynamic modeling and simulation. GPS-X is also uses the most recent advances in process modeling, simulation technology, graphics and a host of productivity tools that simplify model construction, simulation and interpretation of results.

\section{MATERIALS AND METHODS}

\subsection{The Experimental Pilot Plants}

The experimental data which used on the model calibration and verification were taken from experimental work done at TUBITAK, Marmara Research Center, Turkey [3]. The raw black and grey water used in this study were segregated and collected from lodging houses of the TABITAK Campus. As shown in Fig. 1, two pilot scale MBRs having identical configuration, with an effective volume of $600 \mathrm{~L}$ were operated in a sequential batch mode. Both systems include a submerged microfiltration plate and frame module (Kubota). The membrane has a nominal pore size of $0.4 \mu \mathrm{m}$, and is manufactured from a polyelectrolyte complex (PEC) with a total membrane area of $5 \mathrm{~m}^{2}$. Fouling on the surface of the plate and frame module is controlled through tangential flow along the membrane surface by fine and course bubble air scouring. The transmembrane pressure difference is provided by the water head above the membrane. The flux of the systems during the operation period was measured to be $26-36 \mathrm{~L} / \mathrm{m}^{2} \mathrm{~h}$ and $30-40 \mathrm{~L} / \mathrm{m}^{2} \mathrm{~h}$ for grey and black water MBRs respectively. Air is supplied to the MBR by an air blower, which also automatically controls the anoxic aerobic conditions by PLC at predetermined and preadjusted time intervals. Some operational parameters of the systems are given in Table 1.

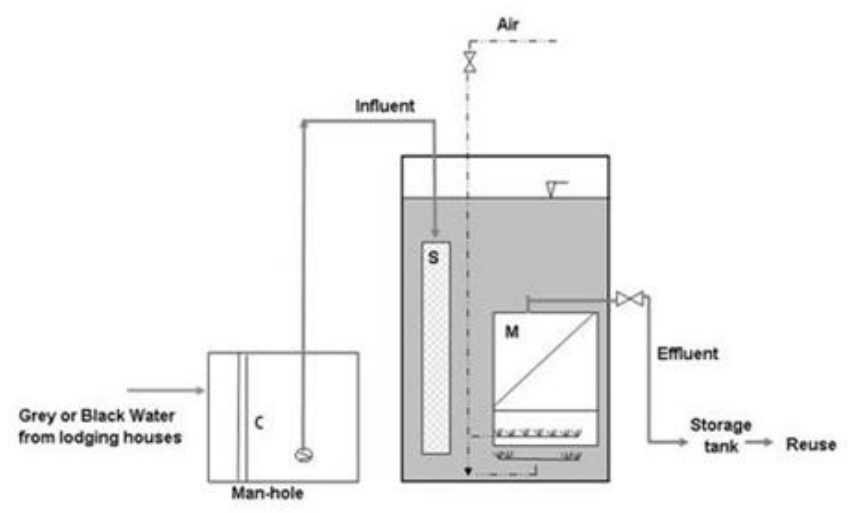

Fig. 1 Schematic of the MBR pilot plant.

Table 1 Operational parameters of the pilot scale MBRs.

\begin{tabular}{|l|c|c|}
\hline Operational Parameter & $\begin{array}{c}\text { Grey } \\
\text { Water }\end{array}$ & $\begin{array}{c}\text { Black } \\
\text { Water }\end{array}$ \\
\hline $\begin{array}{l}\text { Reactor effective volume, } \\
\mathrm{L}\end{array}$ & 600 & 600 \\
\hline Operation time, day & 50 & 50 \\
\hline Influent flow rate, L/d & 800 & 400 \\
\hline Pore size, $\mu \mathrm{m}$ & 0.4 & 0.4 \\
\hline Membrane area, $\mathrm{m}^{2}$ & 5 & 5 \\
\hline Flux, L/m ${ }^{2} . \mathrm{h}$ & $26-36$ & $30-40$ \\
\hline HRT, h & 18 & 36 \\
\hline Cycle number/day & 8 & 4 \\
\hline $\begin{array}{l}\text { Aerobic time before } \\
\text { discharge/cycle, min }\end{array}$ & 33 & 33 \\
\hline Start up MLSS, g/L & 1.5 & 3.0 \\
\hline $\begin{array}{l}\text { Organic loading rate, } \\
\text { kgCOD/m }{ }^{3} . \mathrm{d}\end{array}$ & 0.3 & 0.8 \\
\hline
\end{tabular}

Both MBRs pilot plants were operated for a period of 50 days. As a first approach, the MBR operational mode for grey water treatment was configured to perform 8 cycles in a day. The system was operated in four consequent phases as fill-react-filtration-idle. The reaction period was set to be $33 \mathrm{~min}$ for each cycle. For black water, the MBR operation was similar to the grey water case with exception of accomplishing 4 cycles in a day. For both MBR reactors, a fill volume of $100 \mathrm{~L}$ was selected, leaving $500 \mathrm{~L}$ for stationary volume. Activated sludge supplied from nearby domestic wastewater treatment plant was used for the start-up period, providing a mixed liquor suspended solids concentration (MLSS) of 1.5 and $3.0 \mathrm{~g} / \mathrm{L}$ respectively for grey and black water MBRs. Raw grey and black water characteristics were monitored based on daily composite samples taken from the holding tanks immediately after screen, under the mixing conditions throughout the operational period of the MBRs. Whatman GF/C glass fiber filters with an effective pore size of $1.2 \mu \mathrm{m}$ were used in analysis of volatile suspended solids (VSS) and suspended solids (SS). The soluble COD was also defined as filtrate through Whatman GF/C glass fiber 
filters. All analysis for characterization was performed as defined in standard methods.

\subsection{The MBR Plant Model Configuration and Operation Conditions}

The Membrane bioreactor (MBR) plant model is composed of two primary parts, first part is aeration tank unit responsible for the biological biodegradation of the waste compounds and second part is the membrane module unit for the physical separation of the treated water from mixed liquor. Figure (2) shows the MBR model layout. The MBR system used in the plant can be known as the submerged MBR system because the skin membranes are submerged into the aeration tank. The driving force across the membrane is achieved by creating negative pressure on the permeate side. Cleaning of the membrane is achieved through frequent permeate back pulsing and occasional chemical backwashing. A diffuser is placed directly beneath the membrane module to facilitate scouring of the filtration surface. Aeration and mixing are also achieved by the unit. The MBR kinetic module is based on the ASM1 model, the governing equations of which can be found in Henze et al. [4]. The model has 19 stoichiometric and kinetic parameters, default values of these parameters were used as a starting point for dynamic calibration of the model. The model was calibrated by varying some of the parameters to give the best fit with the experimental data. The model was verified against two set of experiments. First set experiments were grey water operation case and the second set experiments were black water operation case. The GPS-X version 5.0 program was used as simulation software for the MBR model. The operation conditions of the MBR plant were as shown in Table 1.

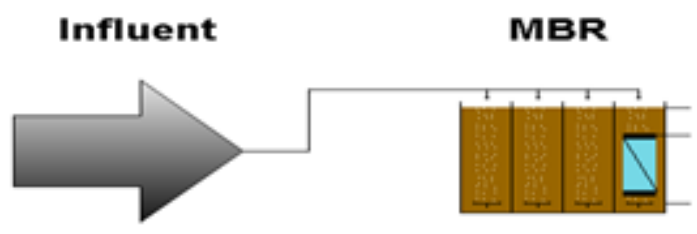

Fig. 2 Schematic of the MBR model plant.

\subsection{Influent Wastewater and Model Scenarios}

The MBR plant model was run by using two scenarios. First scenario was the grey water operation and second scenario was the black water operation. All scenarios were run for 50 days of operation. Influent grey and black wastewater characteristics for both MBR pilot plant and MBR plant model were shown on Table 2.
The results of the raw grey water characterization show that, the $\mathrm{BOD}_{5} / \mathrm{COD}$ ratio was 0.36 , which is slightly lower than the domestic wastewater. The difference can be explained by the higher concentration of soaps and detergents in grey water, which are known to be slowly biodegradable. The average ratio of COD/TKN/T-P for grey water was estimated as

\begin{tabular}{|c|c|c|c|c|c|}
\hline \multirow[b]{2}{*}{ Parameters } & \multirow[b]{2}{*}{ 承尝 } & \multicolumn{2}{|c|}{ Effluent } & \multicolumn{2}{|c|}{ Removal eff. \% } \\
\hline & & $\begin{array}{c}\text { MBR } \\
\text { Model }\end{array}$ & $\begin{array}{l}\text { MBR } \\
\text { Pilot } \\
\text { plant }\end{array}$ & $\begin{array}{c}\text { MBR } \\
\text { Model }\end{array}$ & $\begin{array}{l}\text { MBR } \\
\text { Pilot } \\
\text { plant }\end{array}$ \\
\hline $\mathrm{BOD}_{5}, \mathrm{mg} / \mathrm{L}$ & 90 & 3.8 & 4.5 & 97 & 95 \\
\hline Total COD, mg/L & 245 & 10.5 & 13 & 97 & 95 \\
\hline TKN, mg/L & 9 & 0.4 & 0.55 & 97 & 92 \\
\hline $\mathrm{NH}_{4}^{+}, \mathrm{mg} / \mathrm{L}$ & 1.3 & 0.1 & 0.23 & 94 & 82 \\
\hline $\mathrm{TSS}, \mathrm{mg} / \mathrm{L}$ & 48 & 0.2 & 2 & 99 & 94 \\
\hline
\end{tabular}

$100 / 3.7 / 3$, which is lower for nitrogen but higher for phosphorus compared to the domestic wastewater. This ratio also indicates that grey water is nitrogen limited for biomass growth, which limits the effectiveness of the biological treatment. A higher phosphorus ratio can be explained by the presence of phosphorus containing soaps and detergents in grey water.

The results of the black water characterization show that, the $\mathrm{BOD}_{5} / \mathrm{COD}$ ratio was 0.37 , which shows slightly lower biodegradability as compared to the domestic wastewater. The average ratio of COD/TKN/TP for black water was estimated as $100 / 15 / 1.7$. This ratio indicates that the black water had a high TKN proportion compared to high strength domestic wastewater.

Table 2 Characteristics of grey and black water.

\begin{tabular}{|l|c|c|}
\hline Parameters & Grey water & Black water \\
\hline $\mathrm{pH}$ & 7.1 & 7.6 \\
\hline $\mathrm{T},{ }^{\circ} \mathrm{C}$ & 22 & 22 \\
\hline $\mathrm{BOD}_{5}, \mathrm{mg} / \mathrm{L}$ & 90 & 406 \\
\hline Total COD, mg/L & 245 & 1218 \\
\hline $\begin{array}{l}\text { Soluble COD, } \\
\mathrm{mg} / \mathrm{L}\end{array}$ & 177 & 417 \\
\hline $\mathrm{TKN}^{\mathrm{mg} / \mathrm{L}}$ & 9 & 188 \\
\hline $\mathrm{NH}_{4}{ }^{\circ} \mathrm{mg} / \mathrm{L}$ & 1.3 & 155 \\
\hline $\mathrm{T}-\mathrm{P}, \mathrm{mg} / \mathrm{L}$ & 7.3 & 21.3 \\
\hline $\mathrm{TSS}, \mathrm{mg} / \mathrm{L}$ & 48 & 560 \\
\hline $\mathrm{VSS}, \mathrm{mg} / \mathrm{L}$ & 39 & 475 \\
\hline $\begin{array}{l}\text { Oil and Grease, } \\
\mathrm{mg} / \mathrm{L}\end{array}$ & $<2$ & 26 \\
\hline TDS, mg/L coliform & 13634 & 610 \\
\hline $\begin{array}{l}\text { Total coliform } \\
\text { /100mL }\end{array}$ & 3565 & $>10^{6}$ \\
\hline $\begin{array}{l}\text { Feacal } \\
\text { /100mL }\end{array}$ & & \\
\hline
\end{tabular}

\section{RESULTS AND DISCUSSION}

\subsection{Grey water Operation Case}

The proposed IWA (ASM1) model for the grey water operation case of the MBR plant was run for 50 days of operation at influent $\mathrm{BOD}_{5} 90 \mathrm{mg} / \mathrm{l}$. Table 3 shows the summary of results of effluent concentrations and the removal efficiency of grey water operation case for the 
MBR model and MBR pilot plant. Respectively, figures $3,4,5$ and 6 show the relation between effluent $\mathrm{BOD}_{5}$, $\mathrm{COD}, \mathrm{NH}_{4}$ and TKN with time for both MBR model and MBR pilot plant. The $\mathrm{BOD}_{5}$ and $\mathrm{COD}$ removal efficiency for the MBR model were $96 \%$ and $96 \%$ respectively. Whereas, the removal efficiency of total nitrogen TKN and ammonia nitrogen $\mathrm{NH}_{4}$ for the MBR model were $96 \%$ and $92 \%$ respectively. Also, the total suspended solid TSS removal efficiency was more than $99 \%$.

Table 3 Effluent concentrations of grey water for the MBR model and MBR pilot plant.

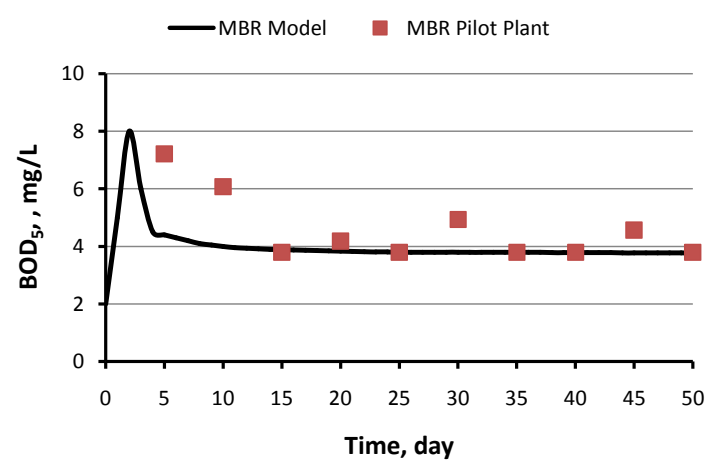

Fig. 3 Relation between effluent $\mathrm{BOD}_{5}$ with time for grey water operation case.

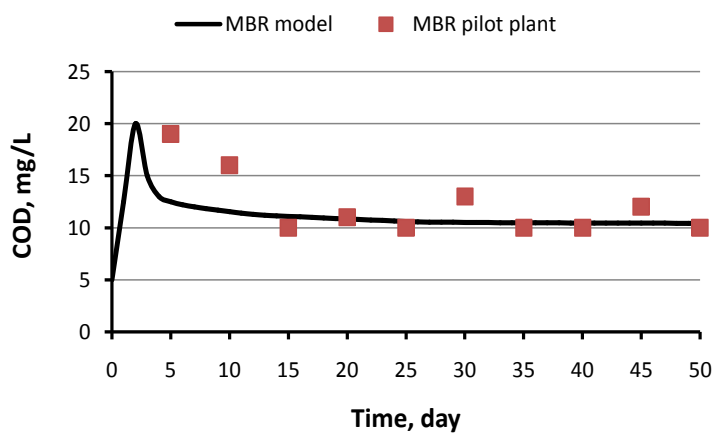

Fig. 4 Relation between effluent COD with time for grey water operation case.

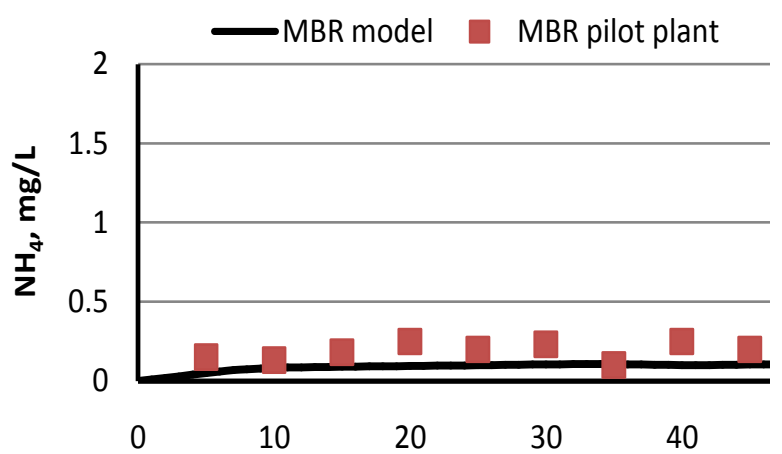

Fig. 5 Relation between effluent $\mathrm{NH}_{4}$ with time for grey water operation case.

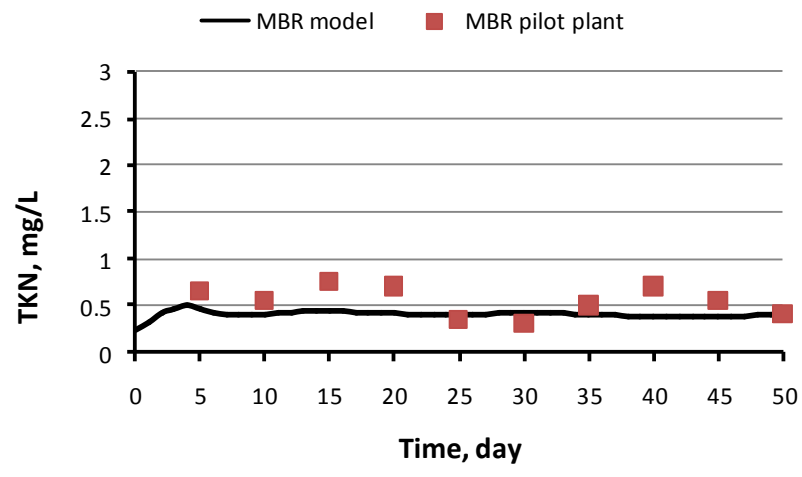

Fig. 6 Relation between effluent TKN with time for grey water operation case.

\section{3. $`$ Black water Operation Case}

The proposed IWA (ASM1) model for the black water operation case of the MBR plant was run for 50 days of operation at influent $\mathrm{BOD}_{5} 406 \mathrm{mg} / \mathrm{l}$. Table 4 shows the summary of results of effluent concentrations and the removal efficiency of black water operation case for the MBR model and MBR pilot plant. Respectively, figures 7, 8, 9 and 10 show the relation between effluent $\mathrm{BOD}_{5}, \mathrm{COD}, \mathrm{NH}_{4}$ and TKN with time for both MBR model and MBR pilot plant. The $\mathrm{BOD}_{5}$ and COD removal efficiency for the MBR model were $98 \%$ and $97 \%$ respectively. Whereas, the removal efficiency of total nitrogen TKN and ammonia nitrogen $\mathrm{NH}_{4}$ for the MBR model were $92 \%$ and $94 \%$ respectively. Also, the total suspended solid TSS removal efficiency was more than $99 \%$.

Table 4 Effluent concentrations of black water for the MBR model and MBR pilot plant

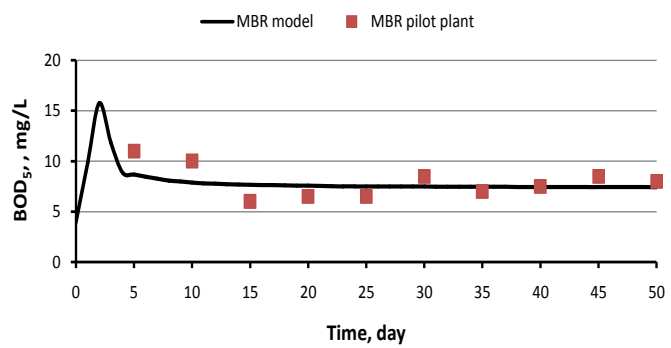

\begin{tabular}{|l|c|c|c|c|c|}
\hline & & \multicolumn{2}{|c|}{ Effluent } & \multicolumn{2}{c|}{$\begin{array}{c}\text { Removal eff. } \\
\%\end{array}$} \\
\hline Parameters & $\begin{array}{c}\text { MBR } \\
\text { MBR } \\
\text { Model }\end{array}$ & $\begin{array}{c}\text { Pilot } \\
\text { plant }\end{array}$ & $\begin{array}{c}\text { MBR } \\
\text { Model }\end{array}$ & $\begin{array}{c}\text { MBR } \\
\text { Pilot } \\
\text { plant }\end{array}$ \\
\hline $\mathrm{BOD}_{5}, \mathrm{mg} / \mathrm{L}$ & 406 & 7.5 & 8 & $9 \wedge$ & 98 \\
\hline Total COD, mg/L & 1218 & 39.5 & 42 & $9 \vee$ & 96 \\
\hline $\mathrm{TKN}^{2} \mathrm{mg} / \mathrm{L}$ & 188 & 14.5 & 19 & $9 \mathrm{r}$ & 90 \\
\hline $\mathrm{NH}_{4}^{+}, \mathrm{mg} / \mathrm{L}$ & 155 & 8.5 & 11 & $9 \varepsilon$ & 93 \\
\hline $\mathrm{TSS}, \mathrm{mg} / \mathrm{L}$ & 560 & 0.6 & $\mathrm{r}$ & 99 & 99 \\
\hline
\end{tabular}

Fig. 7 Relation between effluent $\mathrm{BOD}_{5}$ with time for black water operation case. 


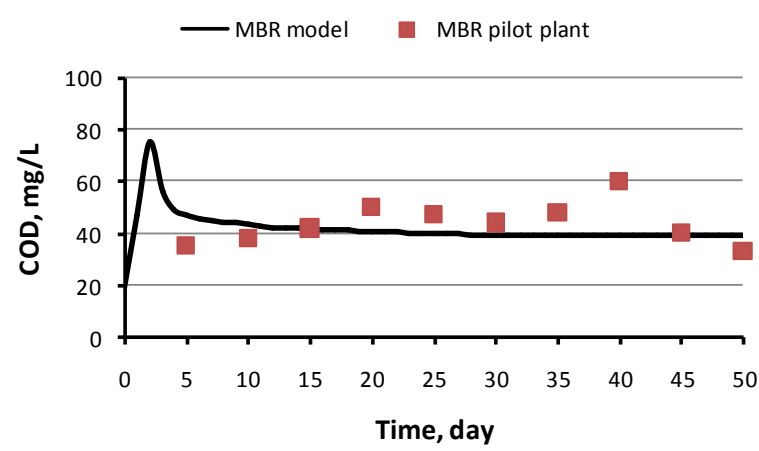

Fig. 8 Relation between effluent COD with time for black water operation case.

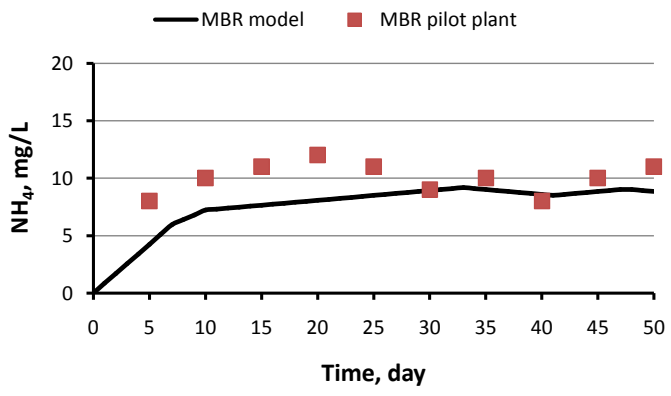

Fig. 9 Relation between effluent $\mathrm{NH}_{4}$ with time for black water operation case.

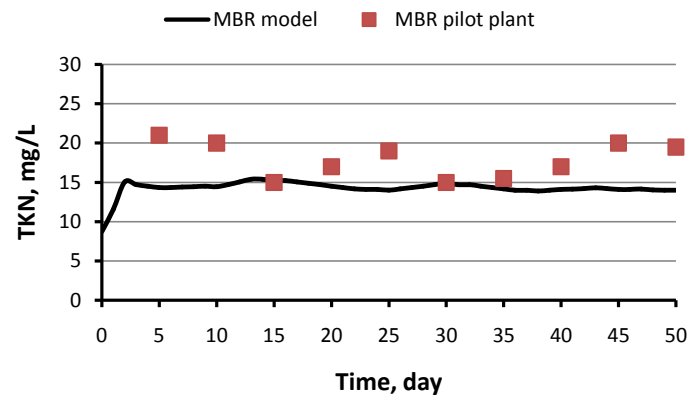

Fig. 10 Relation between effluent TKN with time for black water operation case

The internationally standards like EPA (Environmental Protection Agency, USA) and WHO suggested the reuse standards for several purposes for the treated wastewater $[12,13]$. According to the EPA, suggested guidelines for reuse, especially for the purpose of urban reuse, for all kinds of irrigation, toilet flushing, the concentration of $\mathrm{BOD}_{5}$ should not exceed $10 \mathrm{mg} / \mathrm{l}$, for TSS $5 \mathrm{mg} / \mathrm{l}$, fecal coliform should not be detected in $100 \mathrm{ml}$ sample, and $\mathrm{pH}$ should be in the range of 6-9. The results of this study showed that the effluent quality of the grey and black water treated by the MBR complied with the reuse criteria for different purposes. Since, the grey water pollutant loads are low, the permeate concentrations are found to be quite satisfactory for the purpose of toilet flushing or other household usages that do not need potable water quality.
For the black water, although the aeration period was kept low during the operation, considerable amounts of organic matter and complete TSS removal were attained. It was observed that, for the same reason, complete nitrification and denitrification were not achieved. Although the removal efficiencies are quite good and the permeate is safe from microbial aspect, the results show that a higher removal efficiency must be attained especially for nitrate and ammonia. However, nitrate and ammonia may sill be satisfactory for the point of reuse of permeate for irrigation purposes if some modifications in the operation are made to improve the efficiency.

\section{CONCLUSION}

The model results were verified by using experimental data from two both the MBRs pilot plants. The MBR plant model is powerful tool for optimizing the treatment process and improving the plant operations. Also, the model can be saving significant cost by predicting the outcome of operational changes, as well as, by performing an energy cost analysis. Also, the results show that, the submerged membrane bioreactor is suitable for grey and black water treatment for reuse purposes as a treatment option in the context of sustainable water management and it can be satisfactorily operated under conditions with low and high influent concentrations. It is necessary to provide satisfactory permeate quality for different reuse options, which are believed to be irrigation and toilet flushing in most cases. In accordance with the results, the effluents from both black water and grey water MBR treatment can be adequately reused for toilet flushing and cleaning and irrigation purposes. However, due to the operational risks involved, only the reuse of treated black water for irrigation is recommended. It can be seen that the system requires operational optimization for better black water permeate quality, especially with respect to nitrogen removal. It is recommended that various cycle schedule adjustments be examined in a further study to reach sufficient nitrification and denitrification levels. Furthermore, more research is also required for the determination of the risks of the grey and black water reuse for human contact. Moreover, since the process is a relatively new application for MBR technology, the long term investigation and monitoring of the systems results will be helpful for further applications.

\section{REFERENCES}

[1] Lens P., Zeeman G. and Lettiga G. 'Decentralized sanitation and reuse concept, systems and implementation' IWA Publishing, London 2001.

[2] Nolde E., 'Grey water recycling systems in Germany results, experiences and guidelines' Water Sci. Technol., 51(10), pp 203-210, 2005.

[3] Atasoy E., Murat S., Baban A. and Tiris M. 'Membrane Bioreactor (MBR) Treatment of Segregated Household Wastewater for Reuse' Clean, 35(5), pp 465-472, 2007.

[4] Nolde E. 'Grey water reuse systems for toilet flushing in multi-story buildings over ten years 
experience in Berlin' Urban Water, 1, pp 275-284, 1999.

[5] Lesjean B. and Gnirss R. 'Grey water treatment with a membrane bioreactor operated at low SRT and low HRT' Desalination, 199, pp 432-434, 2006.

[6] Jeferson B., Laine E., Parsons S., Stephenson T. and Judd S. 'Technologies for domestic wastewater recycling' Urban Water, 1, pp 285-292, 1999.

[7] Gildemeister R. and Kraume M. 'Operational experiences in grey water treatment with a submerged membrane sequencing batch reactor (SM-SBR)' MEDAWATER International conference on sustainable water management, Rational water use, Wastewater treatment and reuse, RUWTR, Marrakech, Morocco, 2006.

[8] Judd S., The MBR Book, 'Principles and applications of membrane bioreactors in water and wastewater treatment' Elsevier, Amsterdam, 2006.
[9] Melin T., Jefferson B., Bixio D., Thoeye C., De Wilde W., De Koning J., Van der Graaf J. and Wintgens T. 'Membrane bioreactor technology for wastewater treatment and reuse' Desalination, 187, pp 271-282, 2006.

[10] Benedek,A. and Cote, P. 'Long term experience with hollow fiber membrane bioreactors' International Desalination Association BAH03-180: pp 1-5, 2003.

[11] Orhon D. and Artan N. ' Modeling of Activated Sludge Systems' Technomic Press, Lancaster, PA,1994.

[12] EPA, Guidelines for Water Reuse, U.S Environmental Protection Agency/ U.S Agency for International Development, Washington D.C. USEPA/625/R-04/108, 2004.

[13] WHO, Guidelines for Safe Use of Wastewater, Excreta and Grey Water, Vol. 4, 2006. 